Journal of Maize Research and Development (2016) 2 (1): 109-116

ISSN: 2467-9291 (Print), 2467-9305 (Online)

DOI: http://dx.doi.org/10.3126/jmrd.v2i1.16221

\title{
Evaluation of maize genotypes for Turcicum leaf blight (Exserohilum turcicum) in Terai and inner terai of Nepal
}

\author{
${ }^{1}$ Tirtha Raj Rijal*, ${ }^{1}$ Govind KC, ${ }^{2}$ Kesab Babu Koirala and ${ }^{1}$ Jiban Shrestha \\ ${ }^{1}$ National Maize Research Program, Rampur, Chitwan \\ ${ }^{2}$ Regional Agricultural Research Station, Khajura, Banke \\ *Corresponding author email: tirtha.rijal@yahoo.com
}

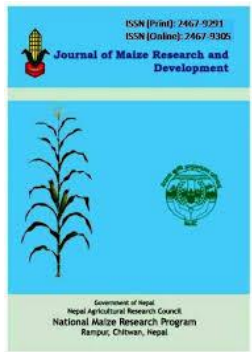

Received: September 2016; Revised: October 2016; Accepted: November 2016

\begin{abstract}
Thirty maize genotypes in 2014-2015 at Dumarwana, Nijgadh, Keureni and Rampur and ten genotypes in 2015-2016 at Anandpur, Shitalnagar, Dumarwana, Nijgadh and Rampur were evaluated for resistance to Turcicum leaf blight (Exserohilum turcicum) under farmers field conditions. The scale used for disease severity ranged from 1-5 scale based on the proportionate leaf area affected by the disease. The combined analysis over locations in 2014-2015 showed that among the 30 genotypes 25 genotypes were resistant (1.0-2.0 scale), and 5 genotypes were moderately resistant (2.1-3.0 scale). Similarly the pooled analysis over locations in 2015-2016 showed that 7 genotypes were resistant (1.0-2.0 scale) and 3 genotypes were moderately resistant (2.1-3.0 scale). The maize genotypes namely Z376-26, Z478-3, Z433-99, Z464-5, Z478-2, Z4661, CAH1513, RML-95/RML-96, CAH1515, CAH1521, CAH1515, CAH151, CAH153, ZH114228, Z376-9, Z466-3, Z376-5, RML-32/RML-17, RML-86/RML-96 and 900MGold were resistant with disease severity scale of 1.5 and with higher grain yield in both the years. Thus above genotypes were identified as promising sources of resistance against E. turcicum and they can be used to develop disease resistant and high yielding varieties to enhance maize productivity in terai and inner terai of Nepal.
\end{abstract}

Key words: resistant, susceptible, genotypes, severity

Correct citation: Rijal, T.R., KC, G., Koirala, K.B., \& Shrestha, J. (2016). Evaluation of maize genotypes for Turcicum leaf blight (Exserohilum turcicum) in terai and inner terai of Nepal.

Journal of Maize Research and Development, 2(1), 109-116,

doi: http://dx.doi.org/10.3126/jmrd.v2i1.16221

\section{INTRODUCTION}

Maize (Zea mays L.) is the second most important staple food crop in Nepal in terms of both area and production after rice. It is the principle food crop in the hills of Nepal. Both abiotic and biotic stresses contribute to lower maize yields in Nepal. The most devastating diseases of 
Journal of Maize Research and Development (2016) 2 (1): 109-116

ISSN: 2467-9291 (Print), 2467-9305 (Online)

DOI: http://dx.doi.org/10.3126/jmrd.v2i1.16221

maize in the context of Nepal are leaf blights (northern and southern), ear rot, stalk rot, rust, downy mildews, etc. (Khadka \& Shah, 1967; Shah, 1968; Thapa, 1977; Manandhar, 1983; Batsa et al., 1989; Paudel et al., 1989). Among the major global issues, food and nutrition security, especially in developing and under developed countries are the biggest challenges of the present agricultural scenario (Ulrich, 2011). For the livestock maize serves as important fodder crop, for human staple food crop and for many agro-allied industries as source of raw materials in the world (Bello et al., 2010; Randjelovic et al., 2011). Turcicum Leaf blight (TLB) of maize caused by Exserohilum turcicum (Pass.) K.J. Leonard and E.G. Suggs (teleomorph Setosphaeria turcica Luttrell) was first observed by Passerini on corn in Italy in 1876, and has been reported from all maize growing areas of the world wherever maize is cultivated (Atac. 1984; Leonard et al., 1985). The pathogen was formerly known as Helminthosporium turcicum (Khedekar et al., 2010; Muiru et al., 2007). Khadka and Shah (1967) reported this disease for the first time in Nepal. TLB, also known as Northern corn leaf blight (NCLB), is more prevalent in the hills during summer and winter to early spring in Terai and Inner terai. The disease occurs in maize from the seedling to maturity stages. The epidemic of the disease is increasing every year in all maize growing areas because of intensive maize cultivation where three maize crops are harvested each year from the same land. TLB reported in 1966 for the first time in Nepal (DAER, 1966) and was not considered as the major disease of maize crop 1985. Temperatures between 20 and 25 ${ }^{0} \mathrm{C}$, relative humidity from 90 to $100 \%$, and low luminosity favor the disease development (Bentolila et al., 1991). In mid-altitude regions where there is high humidity, low temperature and cloudy weather TLB can be severe during the maize growing season (Singh et al., 2004; Harlapur, 2005). Although many maize genotypes have been released from breeding programmes, their reactions to the turcicum leaf blight are largely unknown. This experiment was carried out in order to identify the reaction of maize genotypes to turcicum leaf blight pathogen under field conditions.

\section{Experimental site}

\section{MATERIALS AND METHODS}

The followings locations were selected for the experiments. The geographical details of these sites are as below;

Table 1. Geographic description of experimental locations

\begin{tabular}{llll}
\hline Location & Longitude & Latitude & $\begin{array}{l}\text { Elevation } \\
(\mathrm{m})\end{array}$ \\
\hline Dumarwana (Bara) & $85^{\circ} 1^{\prime} 8.5^{\prime \prime} \mathrm{E}$ & $27^{\circ} 7^{\prime} 55.7^{\prime \prime} \mathrm{N}$ & 124 \\
Nijgadh (Bara) & $85^{\circ} 10^{\prime} 32.5^{\prime \prime} \mathrm{E}$ & $27^{\circ} 12^{\prime} 11.8^{\prime \prime} \mathrm{N}$ & 169 \\
Keureni (Nawalparasi) & $84^{\circ} 12^{\prime} 31.44^{\prime \prime} \mathrm{E}$ & $27^{\circ} 40^{\prime} 22.77^{\prime \prime} \mathrm{N}$ & 178 \\
Shitalnagar (Nawalparasi) & $84^{\circ} 23^{\prime} 21.1^{\prime \prime} \mathrm{E}$ & $27^{\circ} 41^{\prime} 42.5^{\prime \prime} \mathrm{N}$ & 193 \\
Anandpur (Chitwan) & $84^{\circ} 23^{\prime} 13.7^{\prime \prime} \mathrm{E}$ & $27^{\circ} 40^{\prime} 12.1^{\prime \prime} \mathrm{N}$ & 194 \\
Rampur (Chitwan) & $84^{\circ} 20^{\prime} 20.9^{\prime \prime} \mathrm{E}$ & $27^{\circ} 39^{\prime} 0.3^{\prime \prime} \mathrm{N}$ & 182 \\
\hline
\end{tabular}


Field experiments

All field experiments were conducted during winter seasons in 2014-2015 and 20152016 using randomized complete block design (RCBD) with 2 replications at 6 locations of 3 districts namely; Bara (Dumarwana and Nijgadh), Chitwan (Rampur and Anandpur) and Nawalparasi (Keureni and Shitalnagar). The row to row and plant to plant spacing were $60 \mathrm{~cm}$ and $25 \mathrm{~cm}$ respectively. The plot area was $24 \mathrm{~m}^{2}$ in 2014-2015 and $30 \mathrm{~m}^{2}$ in 2015-2016. The fertilizer used was 200:60:40 kg NPK ha ${ }^{-1}$ for all experiments. The recommended package of practices was followed during crop growth according to recommendations given by National Maize Research Program (NMRP), Rampur, Chitwan. Disease severity was measured using scale of 1-5 rating as per CIMMYT protocol (CIMMYT, 1985; Singh et al. 2004).

\section{Data collection and analysis}

Each maize genotype was screened using standard 1-5 scale. According to Payak and Sharma, (1982), 1 scale for complete resistant and 5 for the complete susceptible. Based on this rating scale, the maize lines were categorized into four groups namely, resistant $(\mathrm{R})$ genotypes with a score <2.0; moderately resistant (MR) 2.1-3.0; moderately susceptible (MS) 3.1-3.5 and highly susceptible $(\mathrm{S})>3.5$. Grain yields were adjusted to $80 \%$ shelling recovery. Grain yield was estimated using formula adopted by Carangal et al. (1971) and Shrestha et al. (2015) by adjusting the grain moisture at $15 \%$ and converted to the grain yield $\mathrm{kg}$ per hectare. Data were analyzed through GENSTAT packages applying 5\% significance level.

\section{RESULTS AND DISCUSSION}

Results from individual locations (Table 2) in 2014-2015 showed that at Dumarwana genotypes Z376-9, Z466-3, Z376-5 were resistant with disease severity scale of 1.5 and with grain yield of $>10.5 \mathrm{t} \mathrm{ha}^{-1}$. Similarly at Nijgadh RML-32/RML-17, Z376-26 and Z478-3 were resistant with 1.5 disease severity scale and $>9 \mathrm{t} \mathrm{ha}^{-1}$ grain yield. Likewise at Kuereni Z433-99 and Z464-5 showed resistant reaction having disease severity scale of 1.5 and with grain yield $>11 \mathrm{t} \mathrm{ha}^{-1}$. At Rampur genotypes Z478-2, Z466-1 and 900MGold were resistant (with 1.5 disease severity scale) and grain yield of $>8.5 \mathrm{tha}^{-1}$.

Table 2. Response of maize genotypes for turcicum leaf blight and grain yield $\left(t\right.$ ha $\left.^{-1}\right)$ in 2014-2015 winter

\begin{tabular}{|c|c|c|c|c|c|c|c|c|c|c|c|}
\hline \multirow[t]{2}{*}{$\mathrm{SN}$} & \multirow[t]{2}{*}{ Genotypes } & \multicolumn{2}{|c|}{ Dumarwana } & \multicolumn{2}{|c|}{ Nijgadh } & \multicolumn{2}{|c|}{ Keureni } & \multicolumn{2}{|c|}{ Rampur } & \multicolumn{2}{|c|}{ Combined } \\
\hline & & $\begin{array}{l}\text { TLB. } \\
(1-5)\end{array}$ & GY & $\begin{array}{l}\text { TLB. } \\
(1-5)\end{array}$ & GY & $\begin{array}{l}\text { TLB } \\
(1-5)\end{array}$ & GY & $\begin{array}{l}\text { TLB } \\
(1-5)\end{array}$ & GY & $\begin{array}{l}\text { TLB } \\
(1-5)\end{array}$ & GY \\
\hline 1 & Z478-2 & 1.5 & 10.65 & 1.5 & 8.98 & 1.5 & 8.02 & 1.5 & 9 & 1.5 & 9.2 \\
\hline 2 & Z478-3 & 1.5 & 9.49 & 1.5 & 9.38 & 1.5 & 10.06 & 1.5 & 8.64 & 1.5 & 9.4 \\
\hline 3 & Z478-5 & 1.5 & 9.99 & 1.5 & 8.74 & 1.5 & 8.87 & 1.5 & 8.12 & 1.5 & 8.9 \\
\hline 4 & Z478-4 & 2 & 9.57 & 2 & 9.86 & 1.5 & 10.09 & 2 & 7.74 & 1.9 & 9.3 \\
\hline 5 & Z478-8 & 1.5 & 9.92 & 3 & 6.65 & 1.5 & 8.01 & 2 & 5.95 & 2 & 7.6 \\
\hline 6 & Z480-1 & 2 & 11.37 & 3 & 7.41 & 2.5 & 4.09 & 2.5 & 5.71 & 2.5 & 7.1 \\
\hline 7 & Z478-9 & 2.5 & 6 & 3.5 & 10.59 & 2.5 & 5.13 & 1.5 & 5.17 & 2.5 & 6.7 \\
\hline 8 & Z480-2 & 1.5 & 6.81 & 4.5 & 6.47 & 2 & 6.91 & 2.5 & 5.32 & 2.6 & 6.4 \\
\hline
\end{tabular}


Journal of Maize Research and Development (2016) 2 (1): 109-116

ISSN: 2467-9291 (Print), 2467-9305 (Online) DOI: http://dx.doi.org/10.3126/jmrd.v2i1.16221

\begin{tabular}{llllllllllll}
\hline 9 & Z478-10 & 2.5 & 7.13 & 4.5 & 6.32 & 1.5 & 8.41 & 2 & 5.51 & 2.6 & 6.8 \\
10 & Z433-11 & 1.5 & 10.44 & 1.5 & 6.76 & 1 & 12.29 & 1.5 & 2.89 & 1.4 & 8.1 \\
11 & Z433-99 & 1.5 & 10.27 & 2.5 & 5.77 & 1.5 & 11.42 & 1.5 & 6.27 & 1.8 & 8.4 \\
12 & Z464-5 & 1.5 & 8.81 & 2 & 6.07 & 1.5 & 11.27 & 1.5 & 6.24 & 1.6 & 8.1 \\
13 & Z376-30 & 1.5 & 8.41 & 2 & 3.67 & 1.5 & 9.68 & 1.5 & 5.38 & 1.6 & 6.8 \\
14 & Z466-4 & 1.5 & 7.95 & 3 & 7.64 & 1.5 & 6.24 & 1.5 & 6.34 & 1.9 & 7 \\
15 & Z466-3 & 1.5 & 11.21 & 2 & 6.83 & 1.5 & 9.03 & 1.5 & 7.11 & 1.6 & 8.5 \\
16 & Z466-1 & 1.5 & 10.61 & 3.5 & 7.39 & 1.5 & 7.73 & 1.5 & 8.91 & 2 & 8.7 \\
17 & Z376-2 & 1.5 & 9.86 & 2.5 & 6.36 & 1.5 & 9.38 & 1.5 & 7.97 & 1.8 & 8.4 \\
18 & Z376-5 & 1.5 & 10.62 & 2.5 & 7.84 & 1.5 & 5.41 & 1.5 & 7.25 & 1.8 & 7.8 \\
19 & Z376-6 & 1.5 & 10.07 & 1.5 & 7.96 & 2 & 7.63 & 1.5 & 8.56 & 1.6 & 8.6 \\
20 & Z376-8 & 1.5 & 10.16 & 1.5 & 7.33 & 1.5 & 9.04 & 1.5 & 7.55 & 1.5 & 8.5 \\
21 & Z376-9 & 1.5 & 11.38 & 1.5 & 7.9 & 1.5 & 8.79 & 2 & 7.92 & 1.6 & 9 \\
22 & Z376-26 & 1 & 10.11 & 1.5 & 9.47 & 1.5 & 8.5 & 1.5 & 8.54 & 1.4 & 9.2 \\
23 & Z376-34 & 1.5 & 8.45 & 2.5 & 9.67 & 1.5 & 7.1 & 1.5 & 8.45 & 1.8 & 8.4 \\
24 & Z376-51 & 1.5 & 8.25 & 1.5 & 8.72 & 1.5 & 10.47 & 1.5 & 7.05 & 1.5 & 8.6 \\
25 & 900M Gold & 1.5 & 9.35 & 2 & 7.69 & 1.5 & 7.71 & 1.5 & 8.79 & 1.6 & 8.4 \\
26 & 30V92 & 2.5 & 8.57 & 2 & 10.42 & 3 & 9.09 & 4.5 & 4.95 & 3 & 8.3 \\
27 & RML-32/RML-17 & 2 & 10.64 & 1.5 & 11.37 & 2 & 7.65 & 2.5 & 8.27 & 2 & 9.5 \\
28 & RML-95/RML-96 & 1.5 & 11.15 & 2 & 11.04 & 1.5 & 9.04 & 2 & 7.46 & 1.8 & 9.7 \\
29 & RML-86/RML-96 & 1.5 & 9.74 & 2.5 & 7.63 & 1.5 & 10.94 & 2 & 7.43 & 1.9 & 8.9 \\
30 & Rampur Hybrid-2 & 1.5 & 10.71 & 1.5 & 8.74 & 2 & 9.17 & 2.5 & 6.32 & 1.9 & 8.7 \\
\hline & Mean & 1.6 & 9.59 & 2.3 & 8.02 & 1.7 & 8.57 & 1.8 & 7.03 & 1.9 & 8.3 \\
& F-test & & & & & & & & & $* *$ & $\mathrm{~ns}$ \\
& CV\% & & & & & & & & & 27 & 18.9 \\
& LSD 0.05 & & & & & & & & & 0.7 & 2.2 \\
\hline GY: G & & & & & & & & & \\
\end{tabular}

GY: Grain yield

In 2015-2016 (Table 3) at Nijgadh genotypes CAH1513 and CAH1515 were resistant with disease severity scale of 1.5 and with grain yield of $>7 \mathrm{t} \mathrm{ha}^{-1}$. Similarly at Dumarwana RML95/RML-96, CAH1515 and CAH1521 were resistant with 1.5 disease severity scale and $>7 \mathrm{tha}^{-}$ ${ }^{1}$ grain yield. Likewise at Shitalnagar CAH1521, CAH1515, CAH151 and CAH153 showed resistant reaction having disease severity scale of 1.5 and with grain yield $>11 \mathrm{t} \mathrm{ha}^{-1}$. At Rampur genotypes ZH114228 and CAH153 were resistant (with 1.5 disease severity scale) and grain yield of $>5 \mathrm{t} \mathrm{ha}^{-1}$ and at Anandapur genotypes CAH1515, ZH114228 and RML-86/RML-96 were resistant with grain yield of $>8 \mathrm{tha}^{-1}$.

The maize germplasm with resistance to E. turcicum was previously reported (Muriithi and Mutinda, 2001; Pandurangegowda et al., 2002; Dharanendraswamy, 2003; Harlapur, 2005). Maize susceptibility, cropping practices, and weather conditions strongly influence disease development. The quantitative and qualitative mechanisms control maize resistance to TLB (Hooker, 1981; Ogliari et al., 2007). Quantitative resistance is described by low lesion number, small lesion area having typical necrotic lesion types, along with reduced severity and area under disease progress curve (AUDPC) values; whereas the qualitative resistance is characterized by small lesions surrounded by chlorotic halo also referred to as Ht (Helminthosporium turcicum)lesions type. The results of these experiments showed that resistance reactions for TLB varied with locations and these findings were similar to findings obtained by Welz and Geiger (2000) who reported differential expression of resistance by some varieties when tested at different 
Journal of Maize Research and Development (2016) 2 (1): 109-116

ISSN: 2467-9291 (Print), 2467-9305 (Online)

DOI: http://dx.doi.org/10.3126/jmrd.v2i1.16221

places. The variation in reactions with different climatic conditions was due to environmental factors such as temperature and light that can modify resistance based on Ht genes and also disease pressure varies in different areas.

Table 3. Response of maize genotypes for turcicum leaf blight and grain yield ( $t$ ha $\left.^{-1}\right)$ during winter season of 2015-2016.

\begin{tabular}{llllllllllllll}
\hline SN & Genotypes & \multicolumn{3}{c}{ Nijgadh } & \multicolumn{2}{c}{ Dumarwana } & \multicolumn{3}{c}{ Shitalnagar } & \multicolumn{3}{c}{ Rampur } & \multicolumn{3}{c}{ Anandapur } & \multicolumn{2}{c}{ Combined } \\
& & TLB & GY & TLB & GY & TLB & GY & TLB & GY & TLB & GY & TLB & GY \\
& & $(1-5)$ & & $(1-5)$ & & $(1-5)$ & & $(1-5)$ & & $(1-5)$ & & $(1-5)$ & \\
\hline 1 & CAH158 & 1 & 4.6 & 1.5 & 6.5 & 2 & 11.7 & 2.5 & 4.8 & 2 & 7.6 & 1.8 & 7.03 \\
2 & CAH1521 & 2 & 2.9 & 1.5 & 7.1 & 1.5 & 12.3 & 2 & 4.3 & 1.5 & 11 & 1.7 & 7.51 \\
3 & CAH1513 & 1.5 & 8.4 & 2 & 7.5 & 2 & 11.3 & 3.5 & 2 & 2 & 9.5 & 2.2 & 7.74 \\
4 & CAH1515 & 1.5 & 7 & 1.5 & 7.5 & 1.5 & 12.8 & 2 & 3.5 & 1.5 & 9.4 & 1.6 & 8.02 \\
5 & CAH151 & 2 & 6.8 & 2 & 7.1 & 1.5 & 11.1 & 1 & 3.9 & 1 & 8 & 1.5 & 7.39 \\
6 & CAH153 & 2.5 & 7.7 & 2 & 8.1 & 1.5 & 11.9 & 1.5 & 6.4 & 1.5 & 7 & 1.8 & 8.22 \\
7 & ZH114228 & 3 & 8.5 & 1.5 & 6.2 & 2 & 13.4 & 1.5 & 5.6 & 1.5 & 9 & 1.9 & 8.56 \\
8 & CAH1511 & 2.5 & 8 & 2 & 8.1 & 2.5 & 12.1 & 2 & 5.1 & 1.5 & 6.8 & 2.1 & 8.02 \\
& RML- & & & & & & & & & & & & \\
9 & $95 /$ RML-96 & 3 & 5.1 & 1.5 & 7.7 & 2 & 9.5 & 2 & 3.5 & 2 & 8.7 & 2.1 & 6.88 \\
& RML- & & & & & & & & & & & & \\
10 & 86/RML-96 & 2.5 & 5.5 & 2 & 7.4 & 1.5 & 9.1 & 1.5 & 3.5 & 1.5 & 9.7 & 1.8 & 7.04 \\
\hline & Mean & 2.15 & 6.45 & 1.75 & 7.32 & 1.8 & 11.52 & 1.95 & 4.26 & 1.6 & 8.67 & 1.9 & 7.64 \\
& F-test & & & & & & & & & & & $*$ & $*$ \\
& CV\% & & & & & & & & & & & 26.3 & 17.9 \\
& LSD 0.05 & & & & & & & & & & & 0.6 & 1.76 \\
\hline
\end{tabular}

GY: Grain yield

Table 4. Pooled reaction (over locations) to TLB of maize genotypes in 2014-2015 and 2015-2016

\begin{tabular}{|c|c|c|c|c|c|}
\hline $2014 / 15$ & & & & $2015 / 16$ & \\
\hline Genotypes & Reaction & Genotypes & Reaction & Genotypes & Reaction \\
\hline Z478-2 & $\mathrm{R}$ & Z466-1 & $\mathrm{R}$ & CAH158 & $\mathrm{R}$ \\
\hline Z478-3 & $\mathrm{R}$ & $\mathrm{Z} 376-2$ & $\mathrm{R}$ & CAH1521 & $\mathrm{R}$ \\
\hline Z478-5 & $\mathrm{R}$ & Z376-5 & $\mathrm{R}$ & CAH1513 & MR \\
\hline Z478-4 & $\mathrm{R}$ & Z376-6 & $\mathrm{R}$ & CAH1515 & $\mathrm{R}$ \\
\hline Z478-8 & $\mathrm{R}$ & Z376-8 & $\mathrm{R}$ & CAH151 & $\mathrm{R}$ \\
\hline Z480-1 & MR & Z376-9 & $\mathrm{R}$ & CAH153 & $\mathrm{R}$ \\
\hline Z478-9 & MR & Z376-26 & $\mathrm{R}$ & ZH114228 & $\mathrm{R}$ \\
\hline $\mathrm{Z} 480-2$ & MR & Z376-34 & $\mathrm{R}$ & $\begin{array}{l}\text { CAH1511 } \\
\text { RML- }\end{array}$ & MR \\
\hline Z478-10 & MR & Z376-51 & $\mathrm{R}$ & $\begin{array}{l}\text { 95/RML-96 } \\
\text { RML- }\end{array}$ & MR \\
\hline Z433-11 & $\mathrm{R}$ & 900M Gold & $\mathrm{R}$ & 86/RML-96 & $\mathrm{R}$ \\
\hline Z433-99 & $\mathrm{R}$ & $30 \mathrm{~V} 92$ & MR & & \\
\hline Z464-5 & $\mathrm{R}$ & RML-32/RML-17 & $\mathrm{R}$ & & \\
\hline Z376-30 & $\mathrm{R}$ & RML-95/RML-96 & $\mathrm{R}$ & & \\
\hline
\end{tabular}


Journal of Maize Research and Development (2016) 2 (1): 109-116

ISSN: 2467-9291 (Print), 2467-9305 (Online)

DOI: http://dx.doi.org/10.3126/jmrd.v2i1.16221

Z466-4 R RML-86/RML-96 R

Z466-3 R $\quad$ Rampur Hybrid-2 $\quad \mathrm{R}$

The combined analysis over locations in 2014/15 showed that among the 30 genotypes 25 genotypes were resistant (1-2.0 scale), and 5 genotypes were moderately resistant (2.1-3.0 scale). Similarly the pooled analysis over locations in 2015/16 showed that 7 genotypes were resistant (1-2.0 scale) and 3 genotype was moderately resistant (2.1-3.0 scale) (Table 4).

\section{CONCLUSION}

The maize genotypes namely Z376-26, Z478-3, Z433-99, Z464-5, Z478-2, Z466-1, CAH1513, RML-95/RML-96, CAH1515, CAH1521, CAH1515, CAH151, CAH153, ZH114228 , Z376-9, Z466-3, Z376-5, RML-32/RML-17, RML-86/RML-96 and 900MGold were resistant with higher grain yield. Therefore they can be used in breeding program as potential sources of resistance and can be grown to enhance maize productivity in terai and inner terai of Nepal.

\section{REFERENCES}

Atac, A. (1984). Survey of fungus diseases of second crop maize in the Mediterranean region. Bitkikoruma Bulletin, 24, 137-143.

Batsa B. K., Paudel, D. C., \& Chaudhary, B. (1989). Review of maize disease investigation in Nepal. Proceeding of the fifteenth summer crops workshop. pp. 114.

Bello, O. B., Abdumaliq, S.Y., Afolabi, M.S., \& Ige, S. A. (2010). Correlation and path coefficient analysis of yield and agronomic characters among open pollinated maize varieties and their F1 hybrids in a diallel cross. African Journal of Biotechnology, 9(18), 2633-2639.

Bentolila, S., Guitton, C., Bouvet, N., Sailad, A., Nykaza, S., \& Freyssinet, G. (1991). Identification of RFLP marker tightly linked to the Ht1 gene in maize. Theoretical Applied Genetics, 82, 393-398.

Carangal, V.R., Ali, S.M., Koble, A.F., \& Rinke, E.H. (1971). Comparison of S1 with testcross evaluation for recurrent selection in maize. Crop Science, 11, 658-661.

CIMMYT (1985). Managing trials and reporting data for CIMMYT's International maize testing program. CIMMYT, El Batan, Mexico.

DAER (1966). First Annual report. Department of Agricultural Education and Research. p. 35. Shree Mahal, Pulchowk, Lalitpur, Nepal.

Dharanendraswamy, S. (2003). Studies on turcicum leaf blight of maize caused by Exserohilum turcicum. M.Sc. (Agri.) Thesis, University of Agricultural Sciences, Dharwad.

Harlapur, S. I. (2005). Epidemiology and management of turcicum Leaf blight of maize caused by Exserohilum turcicium (pass.) Leonard and suggs. Ph.D. (Plant Pathology). Thesis, University of Agricultural Sciences, Dharwad 
Journal of Maize Research and Development (2016) 2 (1): 109-116

ISSN: 2467-9291 (Print), 2467-9305 (Online)

DOI: http://dx.doi.org/10.3126/jmrd.v2i1.16221

Harlapur, S. I. (2005). Epidemiology and management of turcicum leaf blight of maize caused by Exserohilum turcicum (Pass.) Leonard and Suggs. Ph.D. Thesis, University Agriculture Science, Dharwad, India.

Hooker, A.L. (1981). Resistance to Helminthosporium turcicum from Tripsacum floridanum incorporated into corn. Maize Genetics Cooperative Newsletter,55, 87-88.

Khadka, B. B., \& Shah, S. M. (1967). Preliminary list of plant disease records in Nepal. Nepal Journal of Agriculture, 2, 47-76.

Khedekar, S. A., Harlapur, S. I., Kulkarni, S., Benagi, V. I., \& Deshpande, V. K. (2010). Integrated management of turcicum leaf blight of maize caused by Exserohilum turcicum (Pass.) Leonard and Suggs. Karnataka Journal of Agricultural Science, 23(2), 372-373.

Leonard, K. J., Levy, Y., \& Smith, D. R. (1989). Proposed nomenclature for pathogenic races of Exserohilum turcicum on corn. Plant Disease, 73, 776-777.

Manandhar, K. L. (1983). The investigation of maize disease in Nepal: Identification and Prevalence. Journal of Institute Agriculture and Animal Science, 4, 45-56.

Muiru, W. M., Mutitu, E. W., \& Kimenju, J. W (2007). Reactions of some Kenyan maize genotype to turcicum leaf blight under greenhouse and field conditions. Asian Journal Plant Science, 6, 1190-1196.

Muriithi LM., \& Mutinda, C.J.M. (2001). Genetic variability of maize genotypes for resistance to Exerohilum turcicum in Kenya. In: 7th Eastern and South Africa Regional Maize Conference February, pp. $11-15$.

Ogliaril, J.B., Guimarães, M.A., \& Camargo L.E.A. (2007). Chromosomal locations of the maize (Zea mays L.) HtP and rt genes that confer resistance to Exserohilum turcicum. Genetics Molecular Biology, 30(3), 630- 634.

Pandurangegowda, K.T., Naik, P., Shetty, T.A.S., Hattappa, S., Naik, N.P., \& Juna, M. (2002). High yielding maize composite NAC 6004 resistant to turcicum leaf blight and downy mildew. Environmental Ecology, 20, 920-923.

Paudel, D. C., \& Chaudhary, B. (1989). Note on some aspects maize pathology in Nepal. In: Proceedings of the fifteenth summer crop workshop. 26-31 Jan., 1992, Rampur, Nepal.

Payak, M. M., \& Sharma, R. C. (1982). Maize diseases and approaches to their management in India. Tropical Pest Management, 31, 302-310.

Ranjdjelovic, V., Prodanovic, S., Tomic, Z., \& Simic, A. (2011). Genotype x year effect on grain yield and nutritive values of maize (Zea mays L.). Journal of Animal Veterinary Science Advances, 10(7), 835-840.

Shah, S. M. (1968). Disease of maize in Nepal. In: Proceedings of the Fifth Inter Asian Corn Improvement Workshop. pp. 159-169.

Shrestha, J., Koirala, K., Katuwal, R., Dhami, N., Pokhrel, B., Ghimire, B., Prasai, H., Paudel, A., Pokhrel, K., \& KC, G. (2015). Performance evaluation of quality protein maize genotypes across various maize production agro ecologies of Nepal. Journal of Maize Research and Development, 1(1), 21-27. doi:http://dx.doi.org/10.3126/jmrd.v1i1.14241

Singh, R, Mani, V. P., Koranga, K. S., Bisht, G. S., Khandelwal, R. S.,, Bhandari, P. \& Pant, S. K. (2004). Identification of additional sources of resistance to Exserohilum turcicum in maize (Zea mays L.). SABRAO Journal of Breeding and Genetics. 36(1), 45-47.

Thapa, G. B. (1977). Maize disease report. In: Proceedings of National Maize Development Workshop, 3, 62-99. 
Journal of Maize Research and Development (2016) 2 (1): 109-116

ISSN: 2467-9291 (Print), 2467-9305 (Online)

DOI: http://dx.doi.org/10.3126/jmrd.v2i1.16221

Ulrich, H. (2011). Assuring food security in developing countries under the challenges of climate change: key trade and development issues of a fundamental transformation of agriculture. United Nations Conference on Trade and Development (UNCTAD). website at http://www.unctad.org.

Welz, H.G., \& Geiger, H.H. (2000). Genes for resistance to Northern corn leaf blight in diverse maize populations. Plant Breeding, 119, 1-14. 